Scientific review article

Received: 15.06 .2016 .

Revised: 19.07.2016.

Approved: 14.09.2016.

\title{
DEVELOPMENT OF THE INSURANCE SECTOR AND ECONOMIC GROWTH IN COUNTRIES IN TRANSITION
}

The main focus of this article is on the insurance sector and economic development of countries in transition; while some of them have already become members of the European Union, others are still in the access to the EU procedure. From the data collected by using an empirical method, it can be observed that the development of the insurance market has had a positive influence on economic growth. The importance of the insurance sector can be observed in the results of the displayed types of insurance in the period from 2010 to 2014. The confirmation of market development is also located in the laid and paid claims, which provide policyholders with security and confidence in insurance companies.

Key words: Insurance, development, economic growth, countries in transition, insurance premium, claims.

* Aleksandra Stojaković, M.S., Underwriter, Insurance company DDOR Novi Sad, Subotica astojakovic0812@gmail.com

** Associate professor Ljiljana Jeremić, PhD, Singidunum University, Belgrade ljjeremic@singidunum.ac.rs. 


\section{Introduction}

Economic development can not be viewed outside the context of the entire social development because the economy is one of the major subsystems of the social system, therefore the economic development is inseparable from the overall social development. Social, political, historical, geographical, cultural and other non-economic domains significantly affect the economic dimensions of the economic development. The economic development is a complex social process by which each country seeks to transit from a lower to a higher stage of economic development, while economic growth is defined as the increase in national production during a period of time greater than population growth. From the provided definition, we see that the economic development is broader and more complex process of economic growth. ${ }^{1}$ There are ways to achieve economic growth along with increased use of inputs in order to increase the output and the optimum use of production capacity. At the same time, the growth of output achieves the same amount of input provided to increase the efficiency of their use. One of the main components of economic development is to modify the social structure and economy, and changes are most pronounced in the manufacturing part, with the participation of the agricultural sector and industry in overall production growth, in order to achieve higher social and national income.

\section{Basic functions of the insurance sector and economic development}

Economic growth can be expressed through the growth rate of the gross domestic product, national income, changes in gross domestic product and national income per capita. Economic development is considered to be an indicator of relations of macroeconomic aggregates such as national product, national income, employment, accumulation, investment, consumption, but also a number of other economic and non-economic factors, therefore it is defined as a multidimensional process. In order to realize economic development, it is necessary to harmonize the pre-defined objectives. Increasing the living standards of the population and the development of the productive potential are two most important goals.

Insurance sector has an important role in our society and other countries in transition, as following:

1) At first, encouraging better risk management in the country and protecting the insured when the worst happens;

2) Likewise, protection provides individuals and businesses with the confidence to engage in economic activity, which leads to general development.

Šulejić Predrag, Vujović Ratko, Mrkšić Dragan, Žarković Nebojša, Rašeta Jovan, Miloradić Jova (2006): Osnovi osiguranja, Univerzitet Singidunum, Beograd, 85. 
3) Also, insurance stimulates economic growth and stability through making long-term investments ${ }^{2}$.

In support of economic growth, insurance regulations need to be strong enough to protect the insured, but not as prescriptive as to prevent insurance companies from supporting economic activity through the products they provide and the investments they make. At the same time, the healthy insurance industry is also required for economic growth, because it is necessary for the insurance sector to remain healthy which requires effective and appropriate regulations.

One should take into account that the number and diversity of the objectives and their dynamism, makes a difficult choice of development priorities. The objectives of economic development depend on the degree of economic development of the country and its size. It would, therefore, be necessary that each country takes into account the right choice of development priorities as well as to provide the material conditions that are important for the achievement of these objectives. One of the indicators of economic development is the share of participation of insurance premiums in the gross domestic product. Through the activities of the insurance, which is part of the financial sector, the ratio of total gross insurance premiums versus gross domestic product (GDP) can be seen, expressed in percentages.

Table 1. The share of insurance premiums in gross domestic product in individual countries compared to the EU for the period 2010 - 2014

\begin{tabular}{|c|c|c|c|c|c|}
\hline & 2010 & 2011 & 2012 & 2013 & 2014 \\
\hline Serbia & $1.80 \%$ & $1.70 \%$ & $1.90 \%$ & $1.80 \%$ & $1.90 \%$ \\
\hline Slovenia & $5.66 \%$ & $5.57 \%$ & $5.70 \%$ & $5.47 \%$ & $5.20 \%$ \\
\hline Croatia & $2.74 \%$ & $2.73 \%$ & $2.75 \%$ & $2.78 \%$ & $2.65 \%$ \\
\hline Montenegro & $2.05 \%$ & $1.97 \%$ & $2.01 \%$ & $2.18 \%$ & $2.11 \%$ \\
\hline Macedonia & $1.52 \%$ & $1.50 \%$ & $1.52 \%$ & $1.44 \%$ & $1.45 \%$ \\
\hline Hungary & $3.13 \%$ & $2.82 \%$ & $2.69 \%$ & $2.71 \%$ & $2.66 \%$ \\
\hline Romania & $1.56 \%$ & $1.38 \%$ & $1.41 \%$ & $1.27 \%$ & $1.21 \%$ \\
\hline EU 27 & $8.40 \%$ & $7.90 \%$ & $6.70 \%$ & $6.80 \%$ & $6.95 \%$ \\
\hline
\end{tabular}

Source: According to data from http://www.nbs.rs, www.huo.hr, www.zav-zdruzenje. si, www.ano.me, www.aso.mk, www.asfromania.ro, www.mabisz.hu, Annual reports Department for Insurance Supervision - 2010, 2011, 2012, 2013, 2014, (09.04.2016.)

Serbia and the countries in the region during the period from 2010 to 2014, according to the criteria of earned insurance premiums, were located well below

http://www.insuranceeurope.eu/search/type/Publication/ How insurance stimulates growth (05.06.2016.) 
the EU average. As far as the structure of insurance is concerned, unlike the countries of the European Union proportions of living under non-life insurance amounted to 2:1, the structure of security in Serbia and the neighboring countries was diametrically opposite. Analyzing the structure of investment portfolio of insurance companies the following conclusions could be provided:

- The largest share in the portfolio had debt securities that in the reporting period accounted for a third of aggregate investment portfolio of insurance companies in Europe. Compared to 2000, in 2010 bonds have increased their share by $35 \%$ and reached the highest level of 2,354 billion (or 35\% of the investment portfolio).

- Other participations were shares that were stable during the reporting period, increased their share and contributed to the greater riskiness of the portfolio of insurance companies. Compared to the year of 2000 participation shares in the investment portfolio of insurance companies in Europe in 2010 increased by about 30\%. However, the increase in the share of stocks was the result of a gradual reduction in the value of debt securities, which had lost $33.8 \%$ in value.

- Loans accounted for the third group of the investment portfolio of insurance companies. In the reporting period, their share was $17 \%$ in 2002 down to $15.4 \%$ in 2010 .

According to the Table 1. it can be concluded that Hungary and Croatia, as the newer Member States of the European Union, are following Slovenia and other EU countries according to the participation of insurance premium in gross domestic product for the period 2010 to 2014, as an important assessment indicator of the situation in the insurance market. The analyzed countries globally have positive trends in their basic macroeconomics; however, their level of economic development is still far from the level of the industrialized countries, which are the founders of the EU.

The global economic crisis on the capital market caused a decline in the price of securities, among which were the ones that were in portfolio insurance companies. But the collapse of the financial system did not endanger the survival of insurance companies in the European financial market, compared to the banking sector, because the insurers invested conservatively their available funds. Insurance companies, while investing, carried out the diversification of the best and least risky securities and therefore their assets have been sold mostly in bonds that have the largest share in their portfolios. The investment portfolio of European insurance companies, compared to 2000, in 2010 increased to 2,100 million euros and it means 6.963 billion euros, which is the highest level of the reporting period. Portfolio of non-life insurance did not significantly change and remained at the level of about 1.000 billion euros, while the life insurance portfolio rose by 2.000 billion euros. The largest share of aggregate European 
investment portfolio was the the United Kingdom ${ }^{3}$, France ${ }^{4}$ and Germany ${ }^{5}$, with the account for over $50 \%$ of the total investments in the domain of life insurance. If we look at the percentage of the portfolio structure, the largest part of the investment portfolio of European insurers accounted for debt securities, followed by actions, loans, real estate and other property. As part of a group of institutional investors, insurance companies have large amounts of capital, invested in different segments of financial markets, primarily in the capital market. The structure of investment depends on the development of financial markets in Europe and the quality of security that insurance companies provide, with much greater opportunities for adequate investment.

In the previous years, at the end of the economic crisis, there were changes in the high rates of growth in GDP in the period 2010 to 2014. The annual analysis that has concluded insurance premiums and paid damages gives the best overview of insurance companies, indicating that regardless of market differences between all regions, many factors have an impact on the expansion of insurance, in both life and non-life. Especially in countries where there is an aging population there is a diversion from the traditional life insurance to pension insurance because the emerging market population is relatively young and generally leads to increased sales of all products ${ }^{6}$.

\section{The state of the financial market in countries in transition}

In contrast to developed countries, where there are significant institutional investors, the countries with the under-developed financial system are at an early stage of development. The data indicate that the insurance companies are far beyond the banking sector, which for years was a leader in the financial market $^{7}$. The balance sheet of the banks in the last six years was above $90 \%$, while the banks' capital in the reporting period did not fall below $85 \%$. Therefore, it is possible to determine that the share of total assets and capital of the insurance sector from year to year was decreased, with the advent of the global economic crisis that reached its lowest level.

The insurance sector in Serbia is less developed and is significantly below the average compared to the member countries of the European Union. In support of these development indicators of the insurance market is the ratio of total

3 BMI Research (2015a): “United Kingdom Insurance Report",http://www.store.bmiresearch. com/united kingdom-insurance-report.html (06.05.2016.)

4 BMI Research(2015b): "France Insurance Report",http://www.store.bmiresearch.com/ france-insurance-report.html (06.05.2016.)

5 BMI Research(2015c):“Germany Insurance Report”,http://www.store.bmiresearch.com/ germany-insurance-report.html (06.05.2016.)

$6 \quad$ OECD.org (2016): "Insurance Guidelines for Economies in Transition", http://www.oecd. org/finance/insurance/insuranceguidelinesforeconomiesintransition.htm(03.06.2016.)

7 Insurance Europe (2014): "Why insurers differ banks", http://www.insuranceeurope.eu/ Whyinsurersdifferbanks (05.06.2016.) 
insurance premiums and gross domestic product and gross premium per capita. It can be concluded that the level of development of the insurance market of a country is conditioned by the level of its economic development. On the other hand, the deep social and economic crisis is still the main characteristic of the macroeconomic environment in which business insurance companies are, whereby insolvent enterprises and impoverished population includes the largest number of policyholders.

Table 2. Realized premiums and structure of the portfolio in Serbia and surrounding countries for the period 2010 - 2014 (in EUR)

\begin{tabular}{|c|c|c|c|c|c|c|}
\hline Country & & 2010 & 2011 & 2012 & 2013 & 2014 \\
\hline \multirow[t]{3}{*}{ Serbia } & TOTAL & $463,065,066$ & $469,786,910$ & $503,800,852$ & $524,930,418$ & $568,893,492$ \\
\hline & life insurance & $16.51 \%$ & $17.44 \%$ & $19.29 \%$ & $21.96 \%$ & $23.06 \%$ \\
\hline & $\begin{array}{c}\text { non- } \\
\text { lifeinsurance }\end{array}$ & $83.49 \%$ & $82.56 \%$ & $80.71 \%$ & $78.04 \%$ & $76.94 \%$ \\
\hline \multirow[t]{3}{*}{ Slovenia } & TOTAL & $2,093,464,202$ & $2,092,244,519$ & $2,036,424,881$ & $1,977,182,583$ & $1,937,555,622$ \\
\hline & life insurance & $27.63 \%$ & $27.95 \%$ & $28.45 \%$ & $30.50 \%$ & $31.34 \%$ \\
\hline & $\begin{array}{c}\text { non- } \\
\text { lifeinsurance }\end{array}$ & $72.37 \%$ & $72.05 \%$ & $71.55 \%$ & $69.50 \%$ & $68.66 \%$ \\
\hline \multirow[t]{3}{*}{ Croatia } & TOTAL & $1,234,384,913$ & $1,220,993,992$ & $1,206,738,985$ & $1,211,829,105$ & $1,143,038,451$ \\
\hline & life insurance & $26.58 \%$ & $26.59 \%$ & $27.23 \%$ & $27.97 \%$ & $30.81 \%$ \\
\hline & $\begin{array}{c}\text { non- } \\
\text { lifeinsurance }\end{array}$ & $73.42 \%$ & $73.41 \%$ & $72.77 \%$ & $72.03 \%$ & $69.19 \%$ \\
\hline \multirow[t]{3}{*}{ Montenegro } & TOTAL & $62,185,580$ & $64,791,699$ & $66,922,021$ & $72,774,509$ & $72,416,868$ \\
\hline & life insurance & $13.45 \%$ & $13.98 \%$ & $14.16 \%$ & $14.94 \%$ & $17.34 \%$ \\
\hline & $\begin{array}{c}\text { non- } \\
\text { lifeinsurance } \\
\end{array}$ & $86.55 \%$ & $86.02 \%$ & $85.84 \%$ & $85.06 \%$ & $82.66 \%$ \\
\hline \multirow[t]{3}{*}{ Makedonia } & TOTAL & $105,638,246$ & $110,974,703$ & $114,322,039$ & $117,254,066$ & $124,380,948$ \\
\hline & life insurance & $5.47 \%$ & $7.30 \%$ & $8.53 \%$ & $10.14 \%$ & $11.64 \%$ \\
\hline & $\begin{array}{c}\text { non- } \\
\text { lifeinsurance }\end{array}$ & $94.53 \%$ & $92.70 \%$ & $91.47 \%$ & $89.86 \%$ & $88.36 \%$ \\
\hline \multirow[t]{3}{*}{ Hungary } & TOTAL & $3,077,806,058$ & $2,941,788,749$ & $2,724,072,598$ & $2,855,039,571$ & $3,006,355,162$ \\
\hline & life insurance & $46.02 \%$ & $47.84 \%$ & $46.85 \%$ & $48.50 \%$ & $48.24 \%$ \\
\hline & $\begin{array}{c}\text { non- } \\
\text { lifeinsurance }\end{array}$ & $53.98 \%$ & $52.16 \%$ & $53.15 \%$ & $51.50 \%$ & $51.76 \%$ \\
\hline \multirow[t]{3}{*}{ Romania } & TOTAL & $1,553,887,606$ & $1,463,268,830$ & $1,855,328,789$ & $1,825,113,816$ & $1,818,821,310$ \\
\hline & life insurance & $20.35 \%$ & $23.00 \%$ & $21.83 \%$ & $20.12 \%$ & $20.29 \%$ \\
\hline & $\begin{array}{c}\text { non- } \\
\text { lifeinsurance }\end{array}$ & $79.65 \%$ & $77.00 \%$ & $78.17 \%$ & $79.88 \%$ & $79.71 \%$ \\
\hline
\end{tabular}

Source: According to data from http://www.nbs.rs, www.huo.hr, www.zav-zdruzenje. si, www.ano.me, www.aso.mk, www.asfromania.ro, www.mabisz.hu, Annual reports Department for Insurance Supervision- 2010, 2011, 2012, 2013, 2014, (09.04.2016.) 
As a result we can see an extremely unfavorable structure of the insurance portfolio in Serbia and other countries in transition; in this regard a comparative analysis of the insurance market was carried out in order to determine the position and level of development of the insurance market in Serbia and in other surrounding countries like Croatia, Slovenia, Montenegro, Macedonia, Romania, and Hungary.

In table 2, we can clearly see that attitude to life and non-life insurance is even, only in Hungary, but in all other mentioned countries where non-life insurance takes precedence over life. It is also interesting that only in Romania life insurance has not experienced tremendous growth, but is occasionally varied, unlike other analyzed countries. Even in Serbia, where a slight shift occurred, from fifth place with $16.51 \%$ share in 2010 to fourth place with the participation of life insurance of about $23.06 \%$ in 2014. Such growth indicator brings us closer to the positive development that is already present in Hungary, Slovenia and Croatia as member states of the European Union, with a higher level of development of the financial sector and the entire economy. Last year, Serbia had an equal ratio of both life and non-life insurance, despite the growth of insurance premiums, as viewed from the standpoint of the insurer accentuated to the need for changes in the design of insurance products, but also the preferences of policyholders. The present expectation is huge with insurance companies with their clients to state intervention that may alter the conditions in the insurance industry. Therefore, a global trend in terms of preferences for clients, such as orientation to the health insurance ${ }^{8}$, change the perspective on life insurance, while the offer in a non-life insurance service has not changed in recent years.

To achieve and maintain the stability of the financial sector, which is a requirement of the finance and investment insurance companies, it is necessary to establish an adequate and continuous supervision of financial institutions. The primary objective of supervision in insurance, in addition to protecting the rights of policyholders and insurance beneficiaries should be the protection of domestic insurers and retention of funds for investment in the domestic financial market, which positively affects the balance of payments of the country. Such planning and organization are very important to attract foreign companies; only under clear and transparent conditions they want to do business, specifically with companies that are at the disposal of foreign companies. The primary task of the NSB is to adequately and timely introduce and implement corrective measures and procedures, as well as to act in full compliance with international procedures and standards applied in the supervision of insurance companies in the EU. The insurance sector, other than being a significant provider of savings and pension products in voluntary pension funds that contribute to old age financial security, is also the European Union's largest institutional investor and provides

Welfare (2016): “Social Insurance and EC Regulations”, http://www.welfare.ie/en/Pages/ Social-Insurance-and-EC-Regulations.aspx (03.06.2016.) 
a steady flow of long-term capital that supports considerably the functioning and stability of financial markets. Investors' performance is much more interesting if based on statistical evidence; the argument holds that individual mutual funds do not considerably, over a long period of time, post better risk-adjusted performance than the broad market averages. ${ }^{9}$

In Serbia, with the entry of foreign companies acquiring green field licenses, insurance companies with foreign ownership have increased recorded participation in the financial market. The changes are seen with insurance companies with foreign ownership, wherein 2010 the prevailing participation in the life insurance premium was $92.5 \%$, in non-life insurance was $61.1 \%$, total assets from $66.7 \%$, the number of employees to $65.6 \%$, while in 2012 the prevailing participation in the life insurance premium was $90.8 \%$, premium in non-life insurance $57.6 \%$, total assets from $68.8 \%$, the number of employees $65.5 \%$ and finally in 2014 the prevailing participation in the life insurance premium reached $91.5 \%$, premium in non-life insurance was $64.7 \%$, total assets from $75.0 \%$, also in the number of employees to $68.8 \%$. In order to succeed in its strategic objective, the NBS has developed a modern control system by which it monitors the insurance companies as well as their exposure to risks. The National Bank has recommended insurance companies to strengthen corporate governance, through the improvement of internal control processes, valuation techniques of investment, risk management ${ }^{10}$, enhancement of transparency and fairness to customers, and active education of potential insured, thus contributing to strengthening trust and further development activities of insurance.

According to the share insurance premium in gross domestic product in 2013 with $1.7 \%$, Serbia was in the 66th place in the world, while this indicator for the EU Member States is as high as $7.5 \%$. However, compared to the group of developing countries with an average of 2.7\%, and the countries of Central and Eastern Europe with an average of $2.0 \%$, and given the fact that countries such as Turkey, Romania, and Russia are behind Serbia, it can be concluded that Serbia is in a satisfactory position. In the period from 2010 to 2014 the development of the insurance market in Serbia, measured by growth in insurance premium retention of goods showed a positive trend. This is primarily a result of applying new accounting by-laws, which established a new structure of financial investments. At the same time, there is a visible decline in the share of real estate in the context of fixed assets. With the progress in the transition process, Serbia and the neighboring countries are becoming aware of the important economic role of insurance and development of the national social security system as recommended by the National Bank of Serbia and the European Union directives. Similarly, countries that

$9 \quad$ Hearth Douglas, Zaima K. Janis (1998): “Contemporary Investments: Security and Portfolio Analysis", Second Edition, Harcourt Brace \& Company, The Dryden Press, Orlando, 664.

10 Jeremić Ljiljana (2010): Istraživanje tržišta i prodaja osiguranja, Univerzitet Singidunum, Beograd, 111. 
have recently integrated into the EU still have many unresolved financial and political problems which affect the development of their economy, while foreign direct investments have not been coming in an expected intensity and have created an unfavorable environment for the development of the insurance market. For example, Hungary was the first Central European country that reformed its insurance system, since the most significant transaction was the biggest sale of state-owned insurance company Hungaria bisztosito to a large consortium of Allianz in $1990^{11}$. Later, on the remains of the global economic crisis, other economic sectors of banking, industrial production, including real estate and car sales have also slowed down the development of the domain of life insurance as a result of higher unemployment and lower income of residents. Data from 2010 to 2014 show signs of a successful recovery of the economy in most countries in transition and the direction to the development of the financial system has certain changes in the operating results of both insurance companies and banks, leasing companies and voluntary pension funds.

\section{Annual review of insurance premiums by insurance companies}

In 2014, in Serbia 25 insurance companies operated, that's three less than in the previous year, 2013, and only one less than in 2010. The insurance business is only dealt with 21 companies, but reinsurance only by four companies. From companies engaged in the insurance business, life insurance exclusively is dealt by six of them, non-life insurance only by nine, and life and non-life insurance by six companies. Observed by ownership, 19 of them are in majority of foreign ownership. On an annual basis, in 2014, insurance companies achieved a total insurance premium in the amount of 69.4 billion dinars, which represents a nominal and real terms increase of $8.4 \%$ and $6.6 \%$, respectively. In 2013 , insurance companies collected the total insurance premium in the amount of 64.0 billion dinars, which represents a nominal and real terms increase of $4.2 \%$ and $2.0 \%$ respectively. That's much higher than in 2010 when the total insurance premium was 56.5 billion dinars. Of the leading insurers, only Dunav insurance had nearly the same insurance premium in 2014 compared to 2013, while Generali and DDOR Novi Sad realized an increase in total annual insurance premium for three consecutive years. Also, a similar trend of growth of insurance premiums had Uniqa and Wiener Insurance, Triglav, Grawe. In Serbia, there is an extremely large difference in the concluded insurance premium in favor of a domestic insurance company, against the Croatian and Montenegrin, as shown in the following representations.

$11 \quad$ Ulst Ingrid (2005): Linkages of Financial Groups in the European Union: Financial Conglomeration Developments in the Old and New Member States, Central European University Press, Budapest, 101. 
Figure 1. Insurance premium per insurance companies in Serbia for the period 2010 - 2014(in RSD)

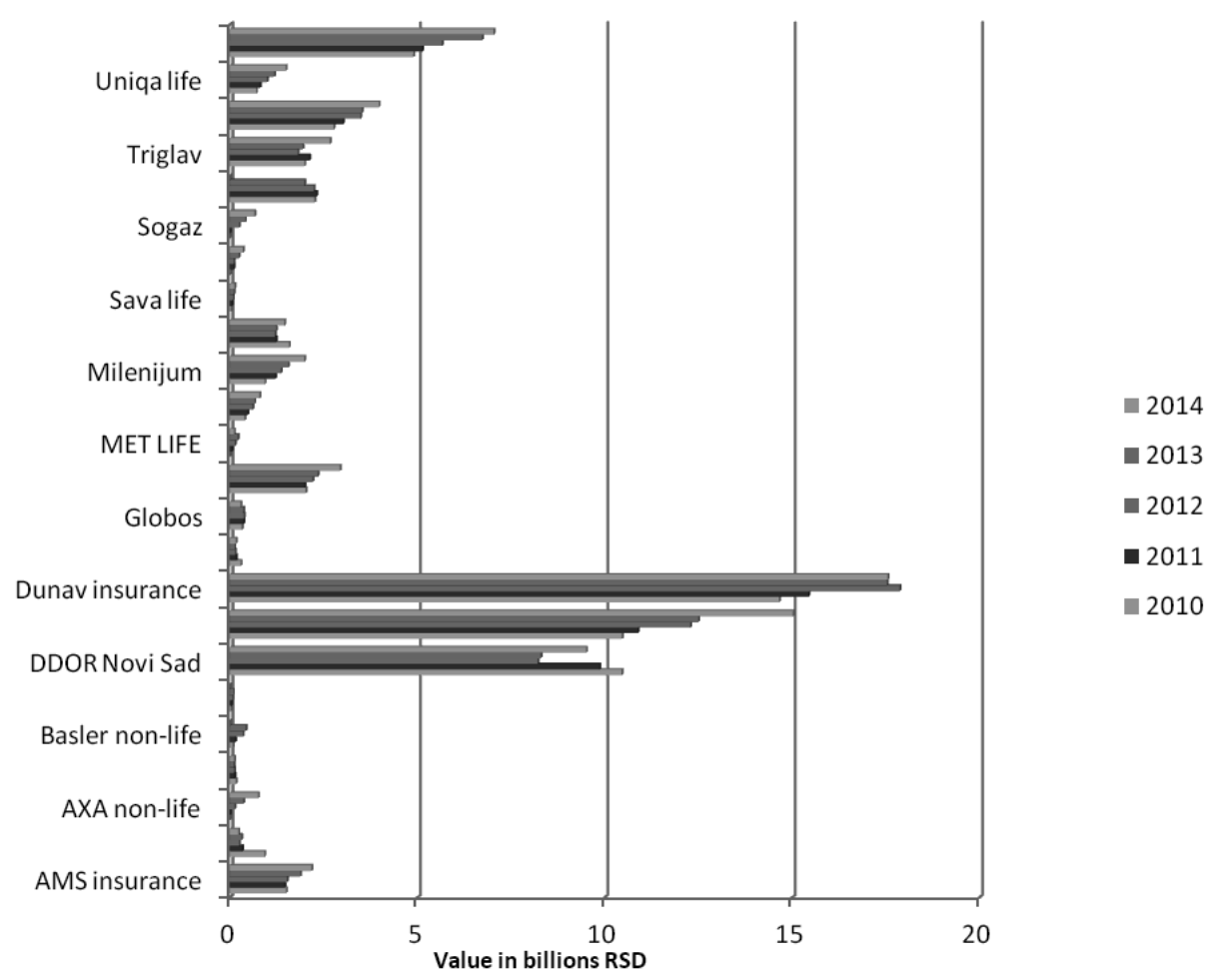

Source: According to data from http://www.nbs.rs, Annual reports Department for Insurance Supervision - 2010, 2011, 2012, 2013, 2014, (09.04.2016.)

It is noticable that Dunav insurance, as the only domestic insurer, is in the first place according to the presence in the insurance market. It is followed by Generali, which is taking over Delta insurance, with quality business policy contributed to an increase in market share. On the other hand, the sale of DDOR Novi Sad to the Italian insurance group Unipol group has not led to success and a better position in the insurance market. An example of quality insurance services provided is Uniqa and Wiener insurance, which is reflected in a significant increase in premiums from year to year.

The most significant change is the sale of Croatia Insurance, a leader in Croatia, the share of which dramatically decreased in 2014 due to privatization and clearing portfolio. Examples of foreign insurers, who are slowly taking over a share of the insurance market, are Allianz, Uniqa, and Wiener insurance companies, where the acquisition of Basler's strengthened its position to approxi- 
mately $7 \%$ market share. The characteristic of the market is the decline in insurance premiums due to the liberalization of automobile insurance, as well as to the new obligations that accompany Croatian accession to the European Union.

Figure 2. Insurance premium per insurers in Croatia for the period $2010-2014$ (in millions EUR)

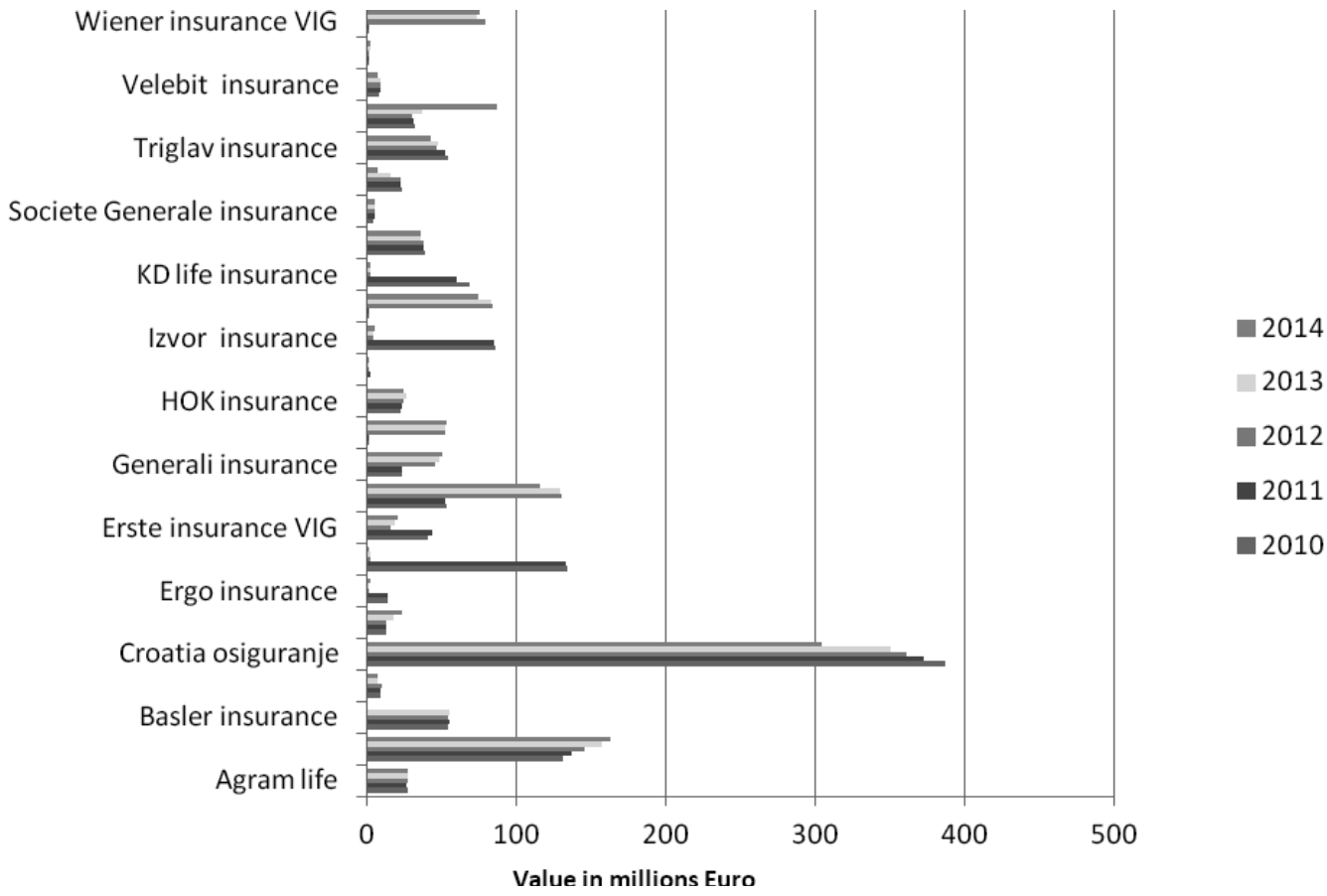

Source: Analysis According to data from www.huo.hr, Annual reports Department for Insurance Supervision- 2010, 2011, 2012, 2013, 2014, (09.04.2016.)

Lovćen Insurance as a former domestic insurer, from 2007 as the property of the Triglav Group, in observed period, has been consistently in first place with a note that in 2014 achieved a significant decrease in insurance premiums due to the decrease in non-life insurance. It is interesting that another Slovenian insurance company Sava Montenegro Insurance has a constant growth in the insurance market in Montenegro. Equal participation and growth can be seen at Delta Generali and Uniqa insurance with minor changes in insurance premiums in 2014. 
Figure 3. Insurance premium per insurance companies in Montenegro for the period 2010 - 2014(in millions EUR)

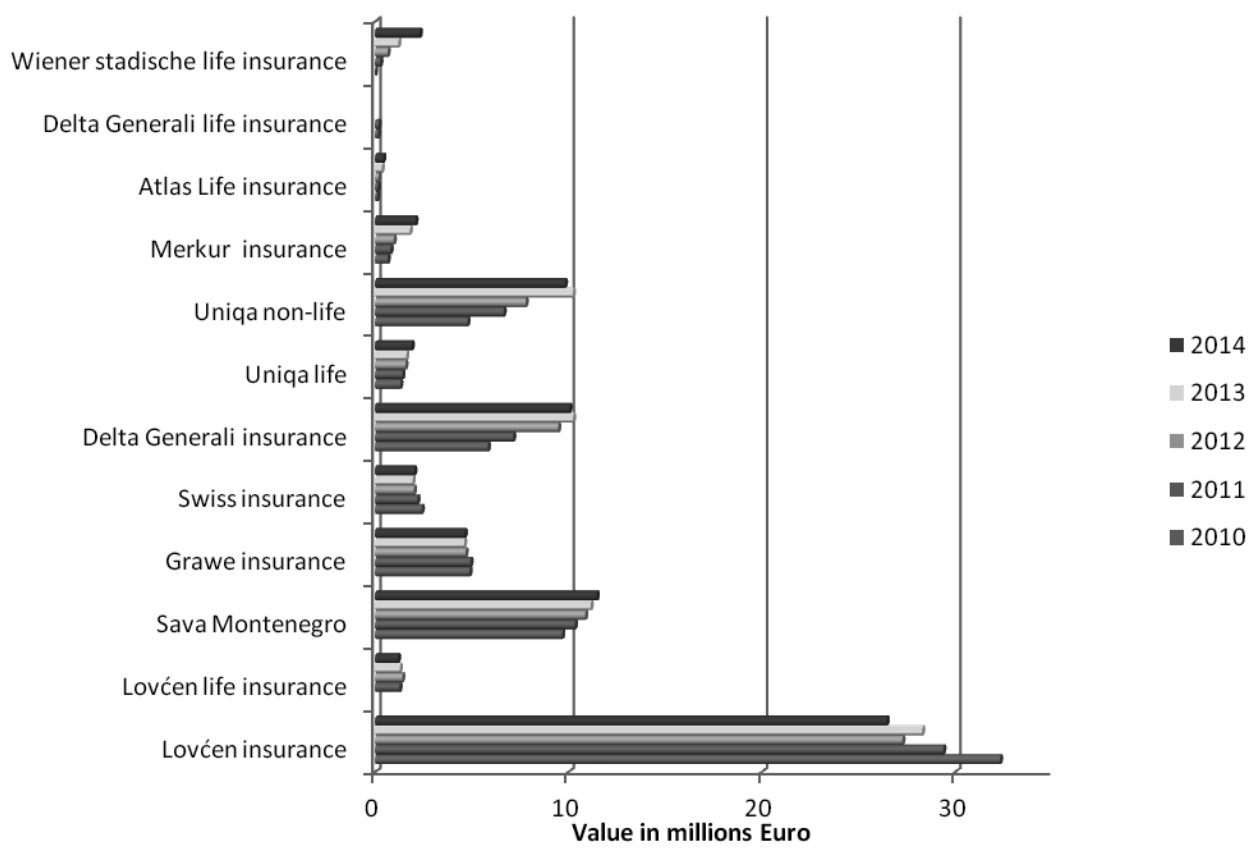

Source: According to data from www.ano.me, Annual reports Department for Insurance Supervision- 2010, 2011, 2012, 2013, 2014, (09.04.2016.)

\section{Annual review of insurance premiums by branches of insurance}

In the insurance premium structure in 2014, the share of non-life insurance amounted to $76.9 \%$, while the share of life insurance increased from $22.0 \%$ in 2013 to $23.1 \%$ in 2014, and compared to the previous year, the achieved increase in life insurance premiums was $13.8 \%$. The premium structure in 2013 mounted the share of non-life insurance to $78.0 \%$, compared to the previous year when the achieved increase in life insurance premiums was $18.6 \%$. Comparing 2014 to recent years, according to the structure of the total portfolio which includes, among other things compulsory insurance, such as insurance of passengers in public transport and employee insurance from accidents, in 2014 a share of 5.8\% was recorded. As in previous years, auto liability insurance in 2014, retains a leading share in the total insurance premium of $32.7 \%$, followed by life insurance with $23.1 \%$ and property insurance with $20.4 \%$. In the total portfolio of five types of non-life insurance accounted for $68.6 \%$ including accident insurance, 
motor insurance, property insurance against fire hazards and property insurance and auto liability insurance(MTPL). MTPL insurance has recorded insurance premium growth of $1.2 \%$, followed by property insurance of $1.6 \%$, while motor insurance - Casco continues the declining trend of premiums of $7.2 \%$ and the share of the total premium to $10.0 \%$.

Figure 4. The insurance premium lines of insurance in Serbia from 2010 to 2014 (in thousands RSD)

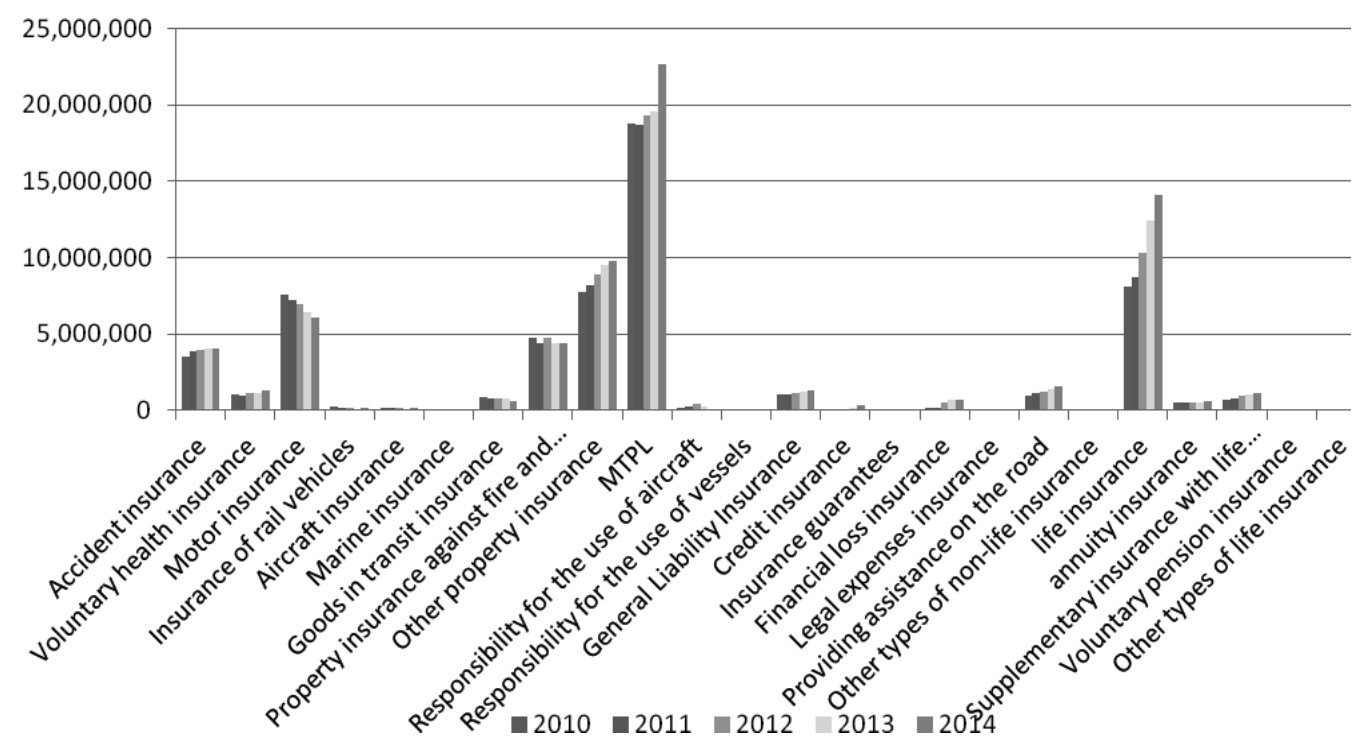

Source: According to data from http://www.nbs.rs, Annual reports Department for Insurance Supervision- 2010, 2011, 2012, 2013, 2014, (09.04.2016.)

Insurance companies can offer life insurance, in addition to the primary savings with risk coverage, introduced along with foreign currency and the dinar currency, but also expanding the range of products adapted to a wider number of people. It is interesting to increase the representation of popular voluntary health insurance or symbolic roadside assistance, indicating the different needs and plans for the future of the insured in relation to the financial possibilities. 
Figure 5. The insurance premium lines of insurance in Croatia from 2010 to 2014 (in millions EUR)

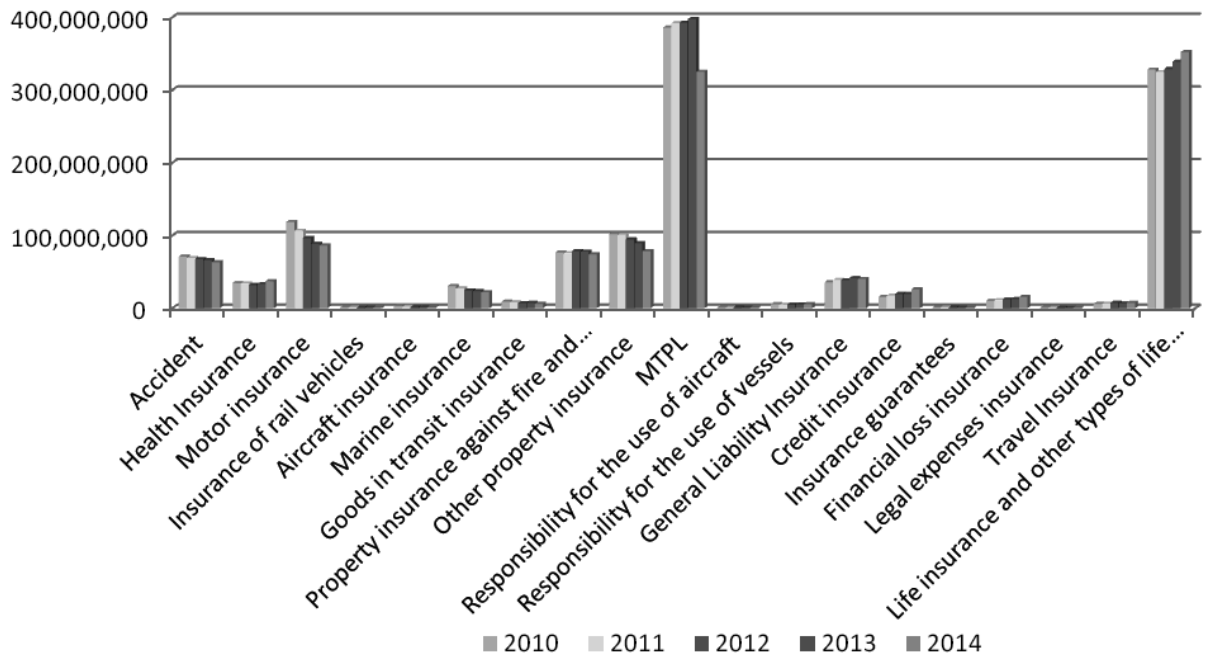

Source: According to data from www.huo.hr, Annual reports Department for Insurance Supervision- 2010, 2011, 2012, 2013, 2014, (09.04.2016.)

Figure 6. The insurance premium lines of insurance in Montenegro from 2010 to 2014 (in millions EUR)

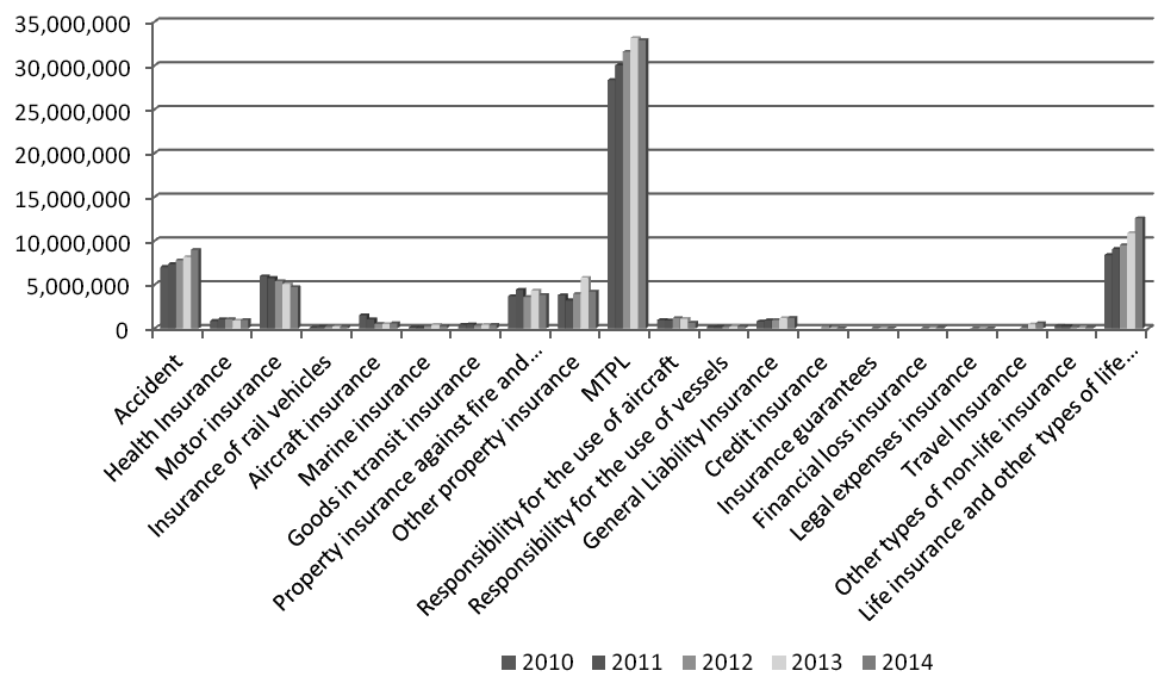

Source: According to data from www.ano.me, Annual reports Department for Insurance Supervision- 2010, 2011, 2012, 2013, 2014, (09.04.2016.) 


\section{Annual review of claims paid by insurance branches}

In the recent history of Serbia and neighboring countries, one of the largest floods occurred in May 2014. According to the official report on the assessment of the damage from the flood, which was adopted by the Government of the Republic of Serbia, the total damage and losses amounted to 1.53 billion euros, which is $4.5 \%$ of gross domestic product in 2013. According to data from 15 insurance companies - insurers, which provide insurance against this risk, total insurance premiums for a flood in 2014 amounted to 648 million, accounting for only $1.2 \%$ of the total life insurance premium. The number of reported claims from 15 May to 31 December 2014 was 3,299, and their amount was 38.8 million euros, representing $0.1 \%$ of gross domestic product and about $2.5 \%$ of the total estimated damage. A society's ability to absorb the risk of inadequate levels of price insurance premiums, unforeseen claims and inadequate transfer of risk of coinsurance and reinsurance is measured by the ratio retention insurance premium and total capital. For companies engaged in non-life insurance, the premium in retention represents an approximation of the assumed risk and should be sufficient for the payment of damages and compensation from the insurance.

Significant improvement in the work sector claim appraisal and settlement reflected in the possibility of electronic reporting of damage, simplifying and improving procedures in dealing with damage, thereby contributing to the efficient work of an insurance company in the interest of better service to its policyholders. The regional business organization, with most insurers, particularly reflected in a more efficient and faster work of appraisers, is the basic link in the chain of resolving damage claims. The new legislation, under the supervision of the National Bank of Serbia, has been introduced to improve th etracking of the resolution of the payment of claims for all insurance companies. Laid claims in the observed period are usually in motor liability insurance, auto insurance, and other property insurance.

One should note the importance of consistent compliance with regulations in the area of compulsory traffic insurance - auto liability, particularly in terms of promptness in the payment of damages, the cost of insurance and the application of the bonus-malus system, through a unified information system for all insurers. Also, there are trainings and preparations for the implementation of the new methodological framework for risk management, because the adequate risk management is essential for the performance of the insurer, which is the essence of the new Directive Solvency II, according to which the consideration of requests from insurers is taken and all risks they are exposed to in their operations to their efficient management quantified. The planned application of the directive requirements is in accordance with the draft of the new Law on Insurance of Serbia's accession to the European Union. 
Figure 7. Paid damages by type of insurance in Serbia in the period 2010- 2014 (in RSD)

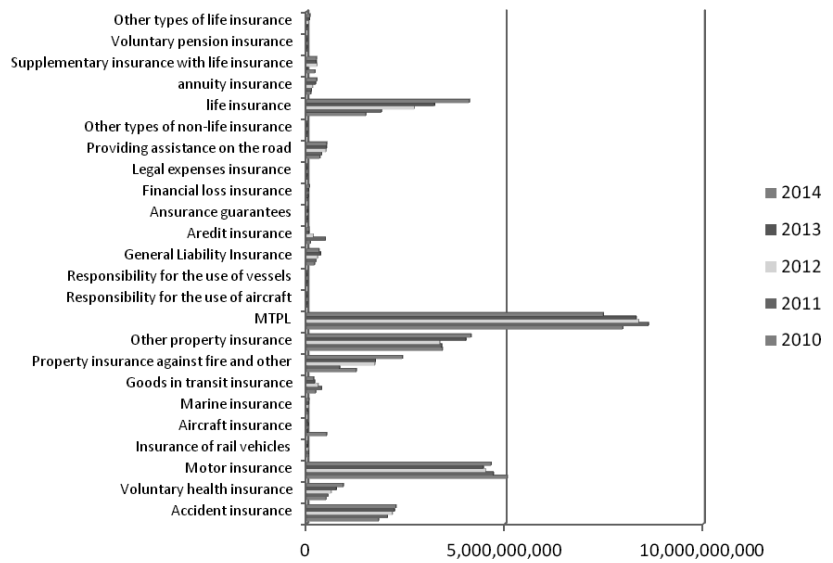

Source: According to data from http://www.nbs.rs, Annual reports Department for Insurance Supervision- 2010, 2011, 2012, 2013, 2014, (09.04.2016.)

Table 4. Paid damages by type of insurance in Croatia in the period 2010-2014 (in millions of EUR)

\begin{tabular}{|l|c|c|c|c|c|}
\cline { 2 - 5 } \multicolumn{1}{c|}{} & 2010 & 2011 & 2012 & 2013 & 2014 \\
\hline Accident & $19,450,794$ & $16,458,792$ & $17,541,340$ & $16,457,879$ & $15,112,549$ \\
\hline Health Insurance & $25,661,186$ & $26,027,641$ & $24,574,479$ & $21,724,253$ & $20,892,420$ \\
\hline Motor insurance & $98,002,410$ & $87,379,696$ & $82,994,877$ & $82,427,989$ & $78,757,744$ \\
\hline Insurance of rail vehicles & 79,373 & 64,347 & 160,911 & 193,574 & 184,910 \\
\hline Aircraft insurance & $1,763,763$ & 278,146 & 75,017 & 651,458 & $1,754,532$ \\
\hline Marine insurance & $11,016,132$ & $12,972,453$ & $15,387,468$ & $11,139,279$ & $12,886,578$ \\
\hline Goods in transit insurance & $5,688,517$ & $2,707,586$ & $2,754,047$ & $1,912,499$ & $1,556,589$ \\
\hline Property insurance against fire and other & $26,365,176$ & $32,688,999$ & $40,112,094$ & $36,727,217$ & $32,991,294$ \\
\hline Other property insurance & $64,331,892$ & $66,085,188$ & $65,248,481$ & $62,036,687$ & $58,416,064$ \\
\hline Responsibility for the use of motor vehicles MTPL & $160,484,682$ & $159,609,593$ & $148,475,249$ & $144,892,820$ & $133,325,090$ \\
\hline Responsibility for the use of aircraft & 2,508 & 517 & 166,117 & 8,776 & 1,701 \\
\hline Responsibility for the use of vessels & 946,143 & 934,734 & 842,155 & 731,188 & $1,004,509$ \\
\hline General Liability Insurance & $14,850,808$ & $14,483,369$ & $17,464,479$ & $19,090,732$ & $18,086,188$ \\
\hline Credit insurance & $14,995,789$ & $13,782,382$ & $9,229,781$ & $5,873,940$ & $4,140,441$ \\
\hline Insurance guarantees & 943,141 & 41,179 & 346,011 & 278,752 & 867,369 \\
\hline Financial loss insurance & $2,560,070$ & $1,639,231$ & $2,204,001$ & $9,565,609$ & $2,663,776$ \\
\hline Legal expenses insurance & 27,690 & 22,747 & 13,956 & 10,105 & 16,842 \\
\hline Travel Insurance & $1,068,911$ & $1,285,197$ & $1,542,473$ & $2,240,012$ & $2,240,673$ \\
\hline Life insurance and other types of life insurance & $138,646,139$ & $173,387,051$ & $189,670,315$ & $208,849,780$ & $204,093,401$ \\
\hline IN TOTAL & $586,885,124$ & $609,848,847$ & $618,803,250$ & $624,812,550$ & $588,992,668$ \\
\hline
\end{tabular}

Source: According to data from www.huo.hr, Annual reports Department for Insurance Supervision - 2010, 2011, 2012, 2013, 2014, (09.04.2016.) 
Table 5. Paid damages by type of insurance in Montenegro in the period 2010-2014 (in millions of EUR)

\begin{tabular}{|l|c|c|c|c|c|}
\cline { 2 - 6 } \multicolumn{1}{c|}{} & 2010 & 2011 & 2012 & 2013 & 2014 \\
\hline Accident & $5,584,642$ & $5,476,200$ & $6,294,452$ & $6,546,134$ & $6,869,439$ \\
\hline Health Insurance & 340,182 & 594,765 & 363,437 & 309,756 & 451,685 \\
\hline Motor insurance & $3,619,064$ & $3,407,337$ & $3,223,752$ & $3,071,032$ & $3,323,748$ \\
\hline Insurance of rail vehicles & 0 & 0 & 97,305 & 314,025 & 0 \\
\hline Aircraft insurance & 0 & 3,552 & 76,415 & 79,953 & 163,380 \\
\hline Marine insurance & 11,645 & 13,342 & 21,833 & 82,632 & 0 \\
\hline Goods in transit insurance & 119,404 & 57,488 & 3,174 & 176,299 & 19,057 \\
\hline Property insurance against fire and other & $1,150,270$ & 421,465 & $1,064,490$ & 539,010 & $1,474,853$ \\
\hline Other property insurance & 0 & 811,982 & 955,251 & $1,328,177$ & $1,436,991$ \\
\hline Responsibility for the use of motor vehicles MTPL & $20,622,810$ & $11,971,721$ & $10,121,054$ & $11,153,711$ & $12,243,261$ \\
\hline Responsibility for the use of aircraft & 26,103 & $-10,139$ & $-12,289$ & 0 & 7,303 \\
\hline Responsibility for the use of vessels & 54,108 & $-19,415$ & 16,882 & 15,715 & 8,175 \\
\hline General Liability Insurance & 79,681 & 66,179 & 109,008 & 93,219 & 274,560 \\
\hline Credit insurance & 79,790 & $-59,004$ & 31,582 & 66,037 & 60,344 \\
\hline Insurance guarantees & 0 & 590 & 4,233 & 61 & 2,159 \\
\hline Financial loss insurance & 0 & 11,843 & $-8,403$ & 0 & 330 \\
\hline Legal expenses insurance & 0 & 0 & 0 & 0 & 0 \\
\hline Travel Insurance & 39,489 & 9,074 & 9,893 & 120,432 & 96,907 \\
\hline Other types of non-life insurance & 0 & 1,012 & 603 & 5,661 & 45,851 \\
\hline Life insurance and other types of life insurance & 0 & 0 & 0 & $2,903,841$ & $4,042,869$ \\
\hline IN TOTAL & $31,727,188$ & $22,757,992$ & $22,372,672$ & $26,805,695$ & $30,520,912$ \\
\hline
\end{tabular}

Source: According to data from www.ano.me, Annual reports Department for Insurance Supervision- 2010, 2011, 2012, 2013, 2014, (09.04.2016.)

\section{Comparative overview of insurance premiums and paid damages for the period from 2010 to 2014}

In addition to the ability of the insurers to make insurance premium at a level sufficient for damages, it is necessary to provide a good collection. Otherwise, the insurer may face the problem of failing to fulfill its obligations to policyholders. Respecting the prescribed rules, control of payments for companies' claims has been conducted by the National Bank of Serbia, which also continues to improve the business practices in the direction of the positive trend related to contracted and paid insurance premiums. Observed analysis of completed insurance premiums and paid damages lead to an important business segment of the insurance company, the consideration of the scope of coverage, which leads to effective risk management. Each insurance company is in a situation which determines the program of reinsurance coverage, as insurance companies 
are exposed to the different possibilities of the damages on the basis of accepted risk of the insured, and thus their different financial stability, management culture and leadership, as well as coverage of risk management. Therefore, due to the specificity of the insurance, companies have different total liabilities and the contracted insurance, a unique approach to creating programs in reinsurance has to be adapted to the real needs covered by each of the insurance company, which has repeatedly protected the interests of all participants of insurance.

The area that insurers deal with is corporate governance, which among other things includes adequately established a system of internal controls, improvement of the risk management, improvement of the valuation techniques of investment, an increase in transparency, strengthening good business practice and fair attitude towards the clients. Timely payment of damages and activities on the education of potential insured contribute to the greater confidence of the insured and create conditions for the development of this segment in the financial system.

According to the figure 8., it is clearly shown that the ratio of claims paid and insurance premiums collected is almost constant over a longer period of time. This information enables insurance companies easier planning of costs, where claims paid occupy a dominant position.

Figure 8. Comparison of the ratio of collected insurance premiums and paid damages in Serbia for the period 2010 - 2014 (in RSD)

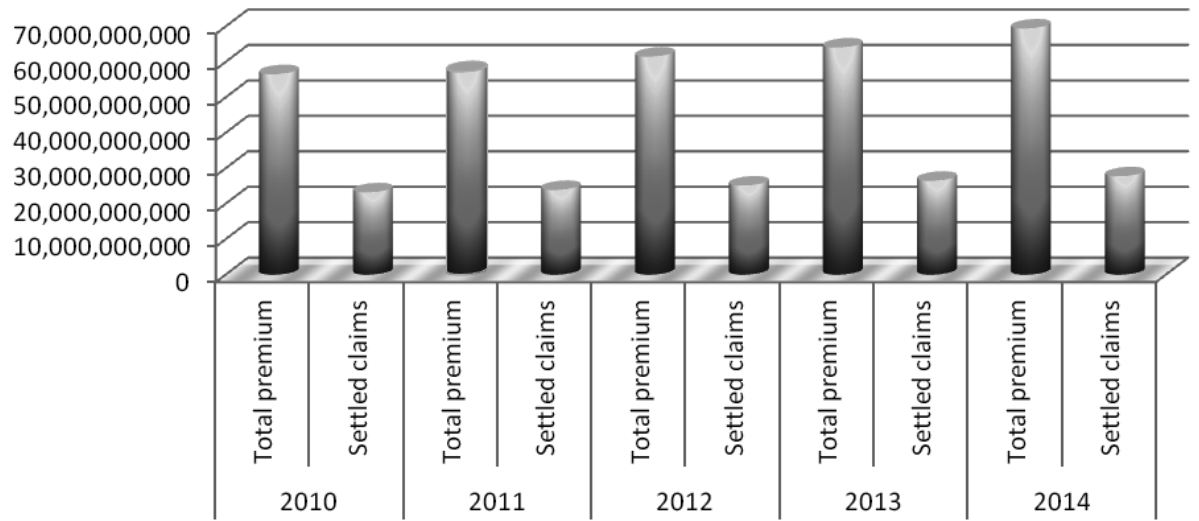

Source: According to data from http://www.nbs.rs, Annual reports Department for Insurance Supervision- 2010, 2011, 2012, 2013, 2014, (09.04.2016.)

Examining the data in figure 9 for insurance premiums and paid damages of the region it can be concluded that a greater percentage of claims has been paid in the Member States of the European Union. The reason for these results is in the development of the insurance market, better education of the insured, as well 
as strengthening the financial power of the insurance companies. A great influence of associations for protection of service users, which is an important market mechanism, can contribute to greater trust and loyalty of policyholders, even though the future is uncertain and society is always in progress creating liberal free market economy ${ }^{12}$. In contrast, less developed countries in transition, including Serbia, have a lower ratio of claims paid in respect of invoiced insurance premiums for diametrically opposite reasons in relation to developed countries of the EU. Insurance premiums reflect the level of economic development of the country. For example Hungary, Slovenia, Romania, and Croatia have significant funds in the insurance sector and the strict legislation gives the possibility of raised funds in further economic trends. Currently Serbia vs. Macedonia and Montenegro only indicates greater potential insurance market for the given parameters.

Figure 9. Comparative review of claims paid and invoiced insurance premiums in the region for the period 2010 - 2014 (in\%)

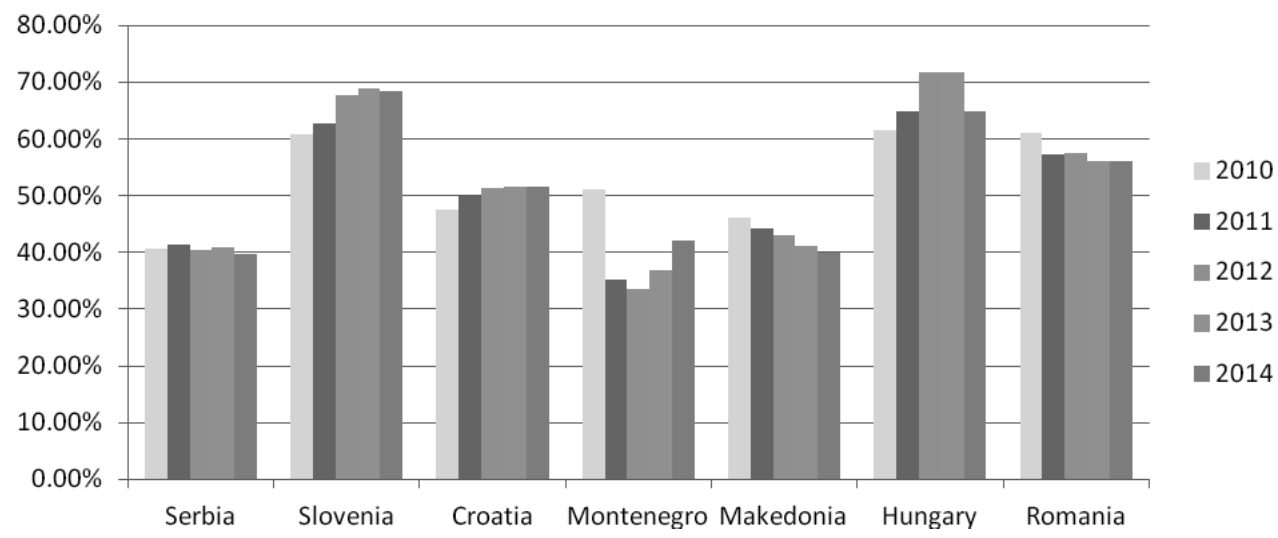

Source: According to data from http://www.nbs.rs, www.huo.hr, www.zav-zdruzenje. si, www.ano.me, www.aso.mk, www.asfromania.ro, www.mabisz.hu, Annual reports Department for Insurance Supervision- 2010, 2011, 2012, 2013, 2014, (09.04.2016.)

It has already been noted that the insurance companies provide transfer of risk, especially when looking at the financial strength of foreign insurance companies, distribution of risk with increasing number of individuals as risk carriers and bearing in mind the likely frequency of occurrence of the risk. Practically, this means that the insurance company is expanding its activities due to the need of new markets or insured, which transfers the risk to a larger number of community members thus expanding the operation risks. This transfer of risk is possible, but also profitable because individuals have a risk averse, which is the basic

12 Turnock David (1997): The East European economy in context: Communism and transition, Routledge, London, 101. 
motive of investments by foreign insurance companies operating in the international market. Insurance companies, therefore, can provide a huge community of insured risks, or population or exposed units, and anticipate the participation costs. It is a very logical investment for insurance companies because they have a power in the accumulation of financial resources and thereby in the weight to new markets where they offer their capital. In economic perspective, insurance in its function provides people and businesses secured financial protection, so that when something bad happens they can maintain a certain standard of living and therefore it makes sense for insurance companies to enable more people and businesses as possible to take out suitable insurance cover ${ }^{13}$. Future expectations, in the long run, are that the conditions of business life insurance and non-life insurance will be difficult, but it can be said that with the development of the economy and the capital market growth the insurance sector is expected to go in a positive direction.

\section{Conclusion}

Using the assessment of collected data, it is shown that the life and nonlife insurance, individually and collectively, contribute to economic growth in a sample of three countries in transition, where two have been the Member States of the European Union, in the period from 2010 to 2014. According to the present development of the results the insurance sector has the opportunity to promote economic growth. At the same time, the functions of insurance companies by providing resources, risk management and allocation of resources, are an important segment for economic growth. The guidelines for work can present some suggestions for future policymakers insurance sector because in the future the insurance companies will assume the position of leading financial investors since they possess large amounts of capital to invest in different segments of the financial market. In any case, the key is to implement usefulness policy that will ensure institutional improvements to the promotion of competition, which contributes to increased efficiency, particularly in risk management and developing new products to ensure. In this regard, many countries deal with demographic challenges and problems in the social security system, which should implement incentive for stimulating an increasing participation of insurance companies in the form of supplementary voluntary pension and health insurance. Due to the development of the insurance sector, it would be possible to contribute to economic growth, as well as to enable future research due to connectivity and data availability in the integration of an increasing number of countries in transition.

13 http://www.insuranceeurope.eu/search/type/Publication/The benefits of insurance (05.06.2016.) 


\section{Literature}

- Agencija za nadzor osiguranja Crna Gora: “Godišnji izveštaj”for 2010, 2011, 2012, 2013, 2014, http://www.ano.me (09.04.2016.)

- Agencija za supervizija na osiguruvanje Republika Makedonija: “Godišnji izveštaj” for 2010, 2011, 2012, 2013, 2014,Preuzeto 09. aprila 2016. sa sajtahttp:// www.aso.mk (09.04.2016.)

- Autoritatea de Supraveghere FinanciarăRomania: "Insurance Report" for 2010, 2011, 2012, 2013, 2014,http://www.asfromania.ro (09.04.2016.)

- BMI Research (2015a):“United Kingdom Insurance Report”, http://www. store.bmiresearch.com/united kingdom-insurance-report.html (06.05.2016.)

- BMI Research (2015b):“France Insurance Report”, http://www.store.bmiresearch.com/france-insurance-report.html (06.05.2016.)

- BMI Research (2015c):“Germany Insurance Report”,http://www.store.bmiresearch.com/germany-insurance-report.html (06.05.2016.)

- EU Commission, (2015): “Company Reporting”,http://ec.europa.eu/finance/ company-reporting/index_en.htm (06.05.2016.)

- Hearth Douglas, Zaima K. Janis (1998): “Contemporary Investments: Security and Prfolio Analysis", Second Edition, Harcourt Brace \& Company, The Dryden Press, Orlando

- Hrvatski Ured za Osiguranje:“Godišnji izveštaj”for 2010, 2011, 2012, 2013, 2014. http://www.huo.hr (09.04.2016.)

- Insurance Europe (2014): "How insurance stimulates growth",http://www. insuranceeurope.eu/search/type/publications/ How insurance stimulates growth (05.06.2016.)

- Insurance Europe (2014):"Why insurers differ banks",http://www.insuranceeurope.eu/Whyinsurersdifferbanks (05.06.2016.)

- Insurance Europe (2015): “The benfits of insurance”, http://www.insuranceeurope.eu/search/type/publication/The benfits of insurance (05.06.2016.)

- Insurance Europe: “Insurance Report” for 2012, 2013, 2014, 2015, 2016, http://www.insuranceeurope.eu (05.06.2016.)

- Jeremić Ljiljana (2010): “Istraživanje tržišta i prodaja osiguranja”, Univerzitet Singidunum, Beograd

- Magyar Biztosítók Szövetsége: "Insurance Report” for 2010, 2011, 2012, 2013, 2014, http://www.mabisz.hu (09.04.2016.)

- OECD.org (2016):“Insurance Guidelines for Economies in Transition”,http:// www.oecd.org/finance/insurance/insuranceguidelinesforeconomiesintransition.htm (03.06.2016.)

- Sektor za nadzor nad obavljanjem delatnosti osiguranja, "Godišnji izveštaj” for2010, 2011, 2012, 2013, 2014, http://www.nbs.rs (09.04.2016.)

- Sigma (2001): "The Insurance Industry in Central and Eastern Europe", No.1/2001, Swiss Re 
- Slovensko zavarovalno združenje Republika Slovenija."Insurance Report”for 2010, 2011, 2012, 2013, 2014, http://www.zav-zdruzenje.si (09.04.2016.)

- Šulejić Predrag, Vujović Ratko, Mrkšić Dragan, Žarković Nebojša, Rašeta Jovan, Miloradić Jova (2006):“Osnoviosiguranja”, UniverzitetSingidunum, Beograd

- Turnock David (1997): “The East European economy in context: Communism and transition", Routledge, London

- Ulst Ingrid (2005):"Linkages of Financial Groups in the European Union: Financial Conglomeration Developments in the Old and New Member States", Central Eurpean University Press, Budapest

- Welfare (2016):“Social Insurance and EC Regulations”, http://www.welfare. ie/en/Pages/Social-Insurance-and-EC-Regulations.aspx (03.06.2016.) 
Aleksandra Stojaković, Ms

Preuzimač rizika, DDOR Novi Sad a.d.o., Subotica

Prof. DR LJILJANA JeREMić

Vanredni profesor, Univerzitet Singidunum, Beograd

\section{RAZVOJ SEKTORA OSIGURANJA I EKONOMSKI RAST U ZEMLJAMA U TRANZICIJI}

U ovom radu sagledava se odnos sektora osiguranja i ekonomski razvoj odabranih zemalja u tranziciji, dok su neke od njih već postale članice Evropske unije, neke druge su još uvek u postupku pristupanja.Iz podataka prikupljenih empirijskom metodom, vidi se da razvoj tržišta osiguranja pozitivno utiče na ekonomski rast. Značaj sektora osiguranja vidi se u rezultatima prikazanih vrsta osiguranja u periodu od 2010. do 2014.godine. Razvijenost tržišta osiguranja posmatra se u rešenim i isplaćenim štetama, koje osiguranicima pružaju sigurnost i poverenje u osiguravajuća društva, a ujedno se doprinosi očuvanju materijalnih resursa društva.

Ključne reči: Osiguranje, razvoj, ekonomski rast, zemlje u tranziciji, premija osiguranja, štete. 